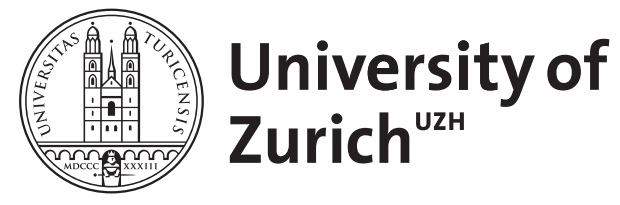

Playing by the rules of the game: partisan use of recall referendums in Colombia

Welp, Yanina ; Milanese, Juan Pablo

DOI: https://doi.org/10.1080/13510347.2017.1421176

Posted at the Zurich Open Repository and Archive, University of Zurich ZORA URL: https://doi.org/10.5167/uzh-157703

Journal Article

Originally published at:

Welp, Yanina; Milanese, Juan Pablo (2018). Playing by the rules of the game: partisan use of recall referendums in Colombia. Democratization, 25(8):1379-1396.

DOI: https://doi.org/10.1080/13510347.2017.1421176 


\section{Playing by the rules of the game: partisan use of recall referendums in Colombia}

\section{Yanina Welp \& Juan Pablo Milanese}

To cite this article: Yanina Welp \& Juan Pablo Milanese (2018) Playing by the rules of the game: partisan use of recall referendums in Colombia, Democratization, 25:8, 1379-1396, DOI: 10.1080/13510347.2017.1421176

To link to this article: https://doi.org/10.1080/13510347.2017.1421176

册Published online: 12 Jan 2018.

Submit your article to this journal

Џll Article views: 106

View Crossmark data $₫$ 


\title{
Playing by the rules of the game: partisan use of recall referendums in Colombia
}

\author{
Yanina Welp ${ }^{a}$ and Juan Pablo Milanese ${ }^{b}$ \\ ${ }^{a}$ Center for Democracy Studies, University of Zurich, Aarau, Switzerland; ${ }^{\text {b Political Studies }}$ \\ Department, Universidad Icesi, Cali, Colombia
}

\begin{abstract}
As a bottom-up mechanism of direct democracy, recall can be triggered by citizens to remove elected officials through a vote, which is expected to increase accountability. Contradicting this hope, previous research has suggested that intensive use of recall referendums became an instrument of party competition. However, empirical evidence is scant. Thus, focusing on the 107 attempts of activating recall in Colombia during the first half of 2017 this article seeks to understand if recall activations are more likely to reinforce democratic governance (by giving an institutional solution to exceptional problems of legitimacy) or are more likely to erode it (by becoming a weapon to escalate the partisan competition beyond regular elections). We created a dataset to identify who started the recall - partisan, mixed or civil society actors - and for what reasons. Then, we examined to what extent the effective number of parties in the council, the majority reached in the previous election, or the size of the municipality have an effect on the likelihood of recall attempts. The study finds that in Colombia, political leaders (and not specific parties) are the main actors promoting recall.
\end{abstract}

ARTICLE HISTORY Received 5 June 2017; Accepted 15 November 2017

KEYWORDS Recall referendum; accountability; legitimacy; political parties; Latin America; Colombia

\section{Introduction}

The recall referendum is a mechanism to allow the removal of an elected official from office before his or her term is complete. When recall is activated by the authorities (that is, by parliament against the executive, referred to as "top down") its logic is similar to an impeachment, but with the extra step of requesting popular legitimation of the decision taken by the parliament or council (for example the impeachment of Romanian president Traian Băsescu that was ratified by a referendum on 29 July 2012). When the mechanism is activated by signature collection (through what is known as a "bottom-up" procedure) it is named "direct recall" (for example, the case of Venezuelan President Hugo Chávez on 15 August 2004 who was confirmed in office).

In Tsebelis' words, bottom-up mechanisms of direct democracy (MDD) (for example, direct recall) allow citizens to become collective veto players ${ }^{1}$ and, in doing so, increase social accountability. However, while an abrogative referendum or a 
citizens' initiative is oriented to reduce the distance between representatives' actions and citizens' preferences, the recall referendum engages in a more delicate task given that its main goal in the short term is not to "reduce distance" (for example, promoting or preventing a policy or institutional change) but to remove the authority.

As Whitehead stresses in his introduction to this special issue, recall is not a new mechanism; however, the practice used to be relatively rare until recently. Latin America is probably the most prolific region introducing regulations to activate recall, with 10 countries offering national or subnational laws in this regard. The same is applicable for the practice of recall, with more than 5000 referendums registered in Peru (the world's most intensive user of recall referendums), around 1000 attempts registered in Ecuador and hundreds in Bolivia and Colombia. ${ }^{2}$

The main question of this article is whether recall works as a mechanism to reinforce democratic governance (by giving an institutional solution to exceptional problems of legitimacy) or on the contrary, erodes it (by becoming a strategy of party competition). We suggest that recall will work as an instrument of democratic governance if it is mainly activated by civil society actors with the aim of holding the challenged politicians accountable. Whereas it will work as an instrument of party competition, if it is mainly activated by political parties or leaders to reach strategic goals out of exceptional political struggles, scandals, or conflicts.

This article builds on the findings provided by the study of the Peruvian case, which suggests that in Peru recall is used as a "party strategy" 3 or party competition. Here, the lack of political party system institutionalization is combined with deep structural problems such as poverty, and insufficient water and energy supplies. At the same time, there is an increase of municipal resources and control of local and regional governments by new parties that are not well connected with national parties. All these factors create a scenario in which self-interested politicians find fertile grounds for political manipulation. In other words, recall procedures may offer incentives in cases where a politician's behaviour prioritizes personal interest over public interest or institutional stability. However, previous research has been based on systemic characteristics of the cases rather than on micro-level data. Thus, more evidence is required to strengthen (or contradict) the idea that parties act (only) strategically and do not lead civic claims for accountability.

Colombia shares some of the features described above. To a lesser extent than Peru, the Colombian case also shows a considerable number of attempts at activating recall. But contrary to Peru, none of these referendums have succeeded thus far. Following a recent amendment of the recall regulation, 107 formal requests were made in the first half of 2017 alone, compared to 161 attempts between 1995 and 2015. This means that if this trend continues, the number of attempts will reach a similar level as in the previous 20 years before the end of the year. In Colombia, the process to activate a recall referendum starts with the registration of a commission. Available data on local elections allow us to identify the promoters, and check if they have participated in previous elections and or if they are affiliated with political parties or are members of civil society organizations. This is complemented by newspaper articles to identify other reasons not detailed in the formal requests. These conditions and data availability make Colombia an ideal case for in-depth analyses of recall through the collection of systematic evidence on the conditions of recall activation. 
The article is structured as follows: first, an overview of recall in Latin America is provided; then, a theoretical framework is offered; third, methodology and case selection are presented; fourth, the analysis is offered and finally, conclusions are drawn.

\section{The Latin American regulation and use of recall}

The recall referendum arrived in Latin America shortly after its introduction at the United States (US) subnational level, ${ }^{4}$ in 1923 and 1933, to Cordoba and Entre Ríos provinces, respectively, both in Argentina; and to Yucatan, Mexico in 1938. It was also introduced in the Constitution of 1940 in Cuba. ${ }^{5}$ However, while practice increased slowly in US cities and states showing a constant increase until now, ${ }^{6}$ the mechanism remained a "dormant institution" 7 in the south of the continent.

This scenario has changed since the 1990s, when several countries replaced their constitutions and introduced recall referendum together with many other mechanisms of direct and participatory democracy. This occurred in Colombia in 1991, Ecuador in 1998 and 2008 (two constitutions were approved in this period), Peru in 1993 and Venezuela in 1999. At the subnational level, recall spread in Argentinian provinces and Mexican states. Other forms of recall have been introduced in Costa Rica where indirect recall is available at the local level to ratify the removal of executive authorities by the Council. Panama stands out as the most exceptional case. Here, recall is designed to resolve internal conflicts within a party, forcing party discipline.

Regarding the jurisdiction, Bolivia, Cuba, Ecuador and Venezuela are among the few countries in the world that permit all elected authorities to be challenged by a recall referendum. ${ }^{8}$ However, in Cuba, this means that only the delegates at the lowest state level can be removed by a referendum because all others are elected by delegates and not the populace. ${ }^{9}$

Table 1 offers an overview of the spread of direct and indirect recall in Latin America and shows the different frequencies of activations. Institutional designs diverge in relation to who can be removed by recall (that is, which authorities or bodies), for what reasons (specified or not), the period of activation (any time, after the first year in office, or before the last year), the number of signatures and the time to collect them, and the actions taken if the authority is removed (replaced by substitutes or call of new elections).

The case of Ecuador shows how the changes in the institutional design dramatically affect the number of activations. In its first introduction in the constitution of 1998, recall activations were allowed in two situations: acts of corruption and failure to accomplish the electoral programme. Surprisingly, in corruption cases, a judicial sentence was required. From 1998 to 2007, no referendums took place. Then, the constitution of 2008 reformulated the recall referendum as a political and participatory right (that is, loss of confidence in the elected authority was enough to trigger a recall), and reduced the number of signatures to $15 \%$. Soon, the number of attempts jumped to almost 1000 (784 officially registered between 2010 and 2011). The institution was reformed again, and since May 2011 requisites are higher, having an evident effect on reducing the number of attempts, which drastically fell to fewer than $100 .^{10}$

Something similar happened in Peru, where the 2013 reform of the law entered into force for the following period had a clear effect, which can be expected to intensify in 
Table 1. Recall regulation in Latin America.

\begin{tabular}{|c|c|c|c|c|c|}
\hline Country & Type of recall & $\begin{array}{l}\text { Year of } \\
\text { introduction }\end{array}$ & Authorities & Attempts* & Votes \\
\hline Argentina $^{a}$ & $\begin{array}{l}\text { Direct and } \\
\text { indirect }\end{array}$ & 1923-1996 & $\begin{array}{l}\text { Executive and legislative authorities } \\
\text { at the subnational level }\end{array}$ & $\begin{array}{c}12 \\
(1923-2014)\end{array}$ & 2 \\
\hline Bolivia & Direct & 2009 & All elected authorities & $\begin{array}{c}216 \\
(2012-2013)\end{array}$ & 0 \\
\hline Colombia & Direct & 1991 & $\begin{array}{l}\text { Executive authorities at the } \\
\text { subnational level }\end{array}$ & $\begin{array}{c}278 \\
(1994-\text { May } \\
\left.2017^{* *}\right)\end{array}$ & 41 \\
\hline Costa Rica & Indirect & 1998 & Executive authorities & $\mathrm{N} / \mathrm{d}$ & 0 \\
\hline Cuba & Direct & 1976 & All elected authorities* & $\mathrm{N} / \mathrm{d}$ & $\mathrm{N} / \mathrm{d}$ \\
\hline Ecuador & Direct & 1998-2008 & All elected authorities & $\begin{array}{c}897 \\
(1998-2016)\end{array}$ & 78 \\
\hline Mexico $^{b}$ & Direct & 1938-2017 & $\begin{array}{l}\text { Executive and legislative authorities } \\
\text { at the subnational level }\end{array}$ & 2 & 0 \\
\hline Panama $^{c}$ & Indirect & 2004 & Legislative authorities & $\mathrm{N} / \mathrm{d}$ & $\mathrm{N} / \mathrm{d}$ \\
\hline Peru & Direct & 1993 & $\begin{array}{l}\text { Executive and legislative authorities } \\
\text { at the subnational level }\end{array}$ & $\begin{array}{c}22,000 \\
(1997-2016)\end{array}$ & 5304 \\
\hline Venezuela & Direct & 1999 & All elected authorities & $\begin{array}{c}167 \\
(1999-2013)\end{array}$ & 10 \\
\hline
\end{tabular}

Note: *The attempts refer to the commissions registered or kits sold (in the case of Peru) oriented to start a process. Numbers are approximate due to the difficulties of accessing complete and accurate information.

**In the case of Colombia, the number for 2017 covers the attempts registered between January and May. Source: own summary based on constitutions, laws and information provided by official electoral institutions. ${ }^{44}$

${ }^{a}$ In Argentina, recall is regulated at the provincial level in Chaco (1957), Chubut (1994), Córdoba (1923, 1987), Corrientes (1960), La Rioja (1986), Rio Negro (1988), Santiago del Estero and Tierra del Fuego (1991); other provinces provide recall for municipalities, namely, Entre Ríos (1933, not included in later constitutions), Neuquén (1957), Misiones (1958), San Juan (1986), San Luis (1987). It is also included in Ciudad de Buenos Aires (1996). ${ }^{45}$

${ }^{b}$ In Mexico, recall is regulated in Oaxaca (1998), Morelos (2011), Guerrero (2013), Zacatecas (2014), Aguascalientes (2014) and Nuevo León (2016), Mexico City (2017). Interestingly, the two attempts registered in Yucatán and Chihuahua led to interventions of the National Judicial Court and the declaration of illegality of the recall, which was removed from the respective constitutions but introduced in many other states. ${ }^{46}$

In Panama, art. 151 of the Constitution establishes recall, which can be used within a political party to remove representatives. It may include popular consultation. The same article mentions that electors could request a recall of members of parliament.

future calls. In the period 2012-2013, around 2000 attempts ended in referendum, while in the following period only 236 referendums were organized. ${ }^{11}$

Other studies also show that attempts of activating recall tend to happen with more frequency in both very small units (where it is easier to activate a referendum) and capitals (where the prize of winning is higher for political actors). ${ }^{12}$ In the Peruvian case, more than $90 \%$ of recall referendums held between 1997 and 2012 took place in communities with an electorate of fewer than $5000 .{ }^{13}$ The next section will explore these issues from a theoretical perspective.

\section{Theoretical discussion}

Recall is defined as an instrument that promotes accountability. The idea behind the regulation of recall referendums is to introduce a mechanism to allow the public to sanction representatives who stray from their promises or their duty to serve their constituents. In other words, it is expected to work as a safety valve for exceptional conflicts. However, institutionalist theories have for a long time argued that institutions do not produce linear or automatic outcomes and may lead to results not originally intended. 
In some Latin American countries, direct recall is defined as a political right (for example, in Peru until 2013, "general dissatisfaction" was enough to initiate a recall process without need of arguments or proof). In other countries, such as Colombia or Ecuador, a formal reason able to be "technically" assessed by electoral bodies is required. In all these countries, recalls have won momentum. A first explanation of this trend could be the crisis of representative democracy. Contemporary societies are characterized by a growing split between the citizenry and the institutions of representative democracy, especially political parties and parliaments. According to some scholars, such a crisis would lead to an increase of direct interventions of citizenry in the political arena. ${ }^{14}$

According to the accountability approach, the reasons behind single activations of recall could be based on the rejection of the authority's performance (direct accountability) or by the rejection of concrete policies (indirect accountability). Research on Japan has shown how recall can be used as a means of "indirect accountability". ${ }^{15}$ This happens when such referendums are used due to the absence of other mechanisms to directly influence a given policy. In the Andean countries, given the growing presence of conflicts regarding mining, water resources, land and other natural resources, recall could be used in this way (that is, to express discontent with authorities in the absence or miss-functioning of other mechanisms of control and decision-making).

However, the literature on bottom-up MDDs underlines the difficulties of activating a process of direct consultation, which often produces high costs in terms of human and financial resources. ${ }^{16}$ In this vein, political parties could be more willing than other actors (for example, labour unions, non-governmental organizations (NGOs) and individual citizens) to undertake such an endeavour. Scholars have suggested that political parties are not necessary against direct democracy and may even profit from it. The Uruguayan and Italian experiences demonstrate how useful referendums can be to mobilize and increase the visibility of a new party in the political arena. ${ }^{17}$ Extending the previous argument, recall may work as a strategy for party competition. However, even if parties could use different devices to mobilize the electorate as happened in these cases, the consequences of promoting or vetoing laws are not equivalent to the consequences of removing authorities before the end of their term. While the first pressures for more accountability and or more negotiations between countries, the second interrupts the mandate and has the potential of creating problems of governability.

The activation of recall may be associated with either exceptional situations (scandals or crises), or with contexts of high political instability. Then, two until now unconnected bodies of literature could suggest explanations to understand the pattern of recall activations: On the one hand, the literature on presidential interruptions; on the other hand, the studies of political party system institutionalization and, in particular, the growing body of literature explaining parties' behaviour at the Latin American subnational level, where recall is more frequently activated.

In his work on impeachments, Pérez-Liñán observed that "recent impeachments constitute the tip of the iceberg of a much broader emerging trend in Latin American Politics". ${ }^{18}$ The use of recall at the subnational level could be the ignored expression of this new trend towards more instability and new patterns of partisan struggle. Scholarly research has approached the issue of "interrupted presidencies" or "presidential breakdown" 19 considering institutional and non-institutional factors and, particularly, the role of oppositions (and situations of divided government) and social mobilization in 
contexts of crisis in interrupting a mandate. Among these studies, elite power struggle and popular support commonly play a major role.

Studies based on subnational politics have emphasized the negative consequences of the erosion of party system institutionalization on governability. In extreme cases, the lack of social rootedness and political parties' low probability of survival from one election to the next could promote anti-system behaviour. ${ }^{20}$ In such contexts of weak party system institutionalization, actors could be incentivized to activate recall referendums and call for new elections. ${ }^{21}$ It is possible to further suggest that a new definition of political organization could be behind recall activations. More than a structured organization, it would refer to leaders fighting for power in contexts of institutional weakness due to flexible and unstable links between groups (inter parties, intra party and including parties and social movements). ${ }^{22}$

In cases like Colombia, different networks of local political actors often move easily from one party label to another (often literally buying the place on the list) or, even, running for positions in more than one party. Thus, the party becomes an electoral machine oriented to win votes (programmatic issues do not matter). In fact, it works as a franchise ${ }^{23}$ in which each local leader specializes in a specific segment of the electorate (as a market). ${ }^{24}$ As a result, the link with the electorate is based on clientelist networks in which (brokers) are more relevant than party labels due to the evident lack of social rootedness. ${ }^{25}$ This produces a scenario of extremely low levels of party system institutionalization $^{26}$ that increases the incentives to activate recall referendums as a power game. $^{27}$

\section{Research design}

We propose that recall will work as a mechanism of democratic governance when it is activated to hold elected politicians accountable. This is more likely the case if is activated by civil society actors and is related to exceptional situations of crisis, scandals or highly controversial policies. Alternatively, we expect recall to be an instrument of party competition if it is mainly activated by partisan leaders, especially, the losers of the previous election, and is not related to exceptional conflicts.

We do not assume that civil society activations are "good" and party activations are "bad" but we believe that they follow a different logic due to the specific reason to activate recall. When a crisis or a scandal is related to the activation, the goal is more likely increasing accountability and to improve democratic governance. However, when there is no special reason (that is, exceptional) to activate recall and the main initiator is a party or a leader who lost in the previous election, recall is more likely to erode democratic governance by introducing instability. Obviously, there can also be mixed situations in which both, political leaders and civil society actors join efforts to activate a recall.

\section{Case selection}

In Colombia, the recall referendum was included by the constituent assembly in the new constitution of 1991. The assembly was organized as an answer to the movement known as "la séptima papeleta" (the seventh ballot), which requested a constitutional reform to end violence, narcoterrorism, corruption and increasing citizenship apathy. Abstention was and still is a characteristic of Colombian politics. Notably, the level of abstention in 
the elections for the constituent assembly reached 75\%. During the debates, the definition of recall referendum in relation to programmatic vote was discussed and approved. It obliges candidates running for office to register a government plan. Once in the post, if a recall is activated arguing that the mayor is not fulfilling the government plan, the programme presented during the campaign is used by the electoral body to assess the validity of the request.

Since the mechanism was introduced by Law 134 in 1994 until 2015, 161 attempts led to 41 referendums and none of them succeeded since the threshold of participation was not reached (see Table 2).

In 2015 , a new law $(303 / 2015)$ reduced the number of signatures required to activate a recall referendum (from $40 \%$ to $30 \%$ of the total of votes obtained by the elected authority) and the threshold required to validate the vote, which if it is not reached does not lead to a decision even if there is a majority in favour of removing the authority (dropping from $50 \%$ to $40 \%$ of valid votes on the day of the elections of the challenged authority). As with the previous regulation, recall can be activated after the first year in government and before the last. The change in the regulation accelerated the recall attempts' registration, leading to a considerable increase in their number. In only five months (January to May), 107 attempts were registered.

\section{Data coding}

We identified a "recall attempt" as the formal intention of removing an authority from office initiated through the presentation of a request at the "Registraduría". This process has to have a speaker or representative of the request (normally includes a list of people supporting the request, identified as the "Comisión Promotora"). Any citizen, social organization, party or political movement can technically initiate the request. The Registraduría has eight days to decide. If the request fulfils the formal requirements, it is allowed to start the signature collection which must be completed within six months. ${ }^{28}$ Data are taken from Registraduría.

The promoter(s) are the speaker and supporters of the formal request presented at the Registraduría. We coded as "political party in the opposition" when the speaker or a relevant number of members of the commission ran for office in previous electoral competitions (like, that is, in in the case of the city of Sabanagrande where the commission has only one member and he did run for office in the previous election). We coded

Table 2. Recall attempts in Colombia from 1995 to May 2017.

\begin{tabular}{lcccc}
\hline Mandate & $\begin{array}{c}\text { Requests } \\
\text { presented }\end{array}$ & $\begin{array}{c}\text { Requests } \\
\text { approved }\end{array}$ & $\begin{array}{c}\text { Recall } \\
\text { referendums }\end{array}$ & $\begin{array}{c}\text { Authorities removed by } \\
\text { recall }\end{array}$ \\
\hline $1994-1996$ & 23 & 5 & 5 & 0 \\
$1997-1999$ & 10 & 6 & 6 & 0 \\
$2000-2002$ & 16 & 5 & 5 & 0 \\
$2003-2006$ & 28 & 10 & 10 & 0 \\
$2007-2010$ & 49 & 11 & 3 & 0 \\
$2011-2014$ & 35 & 14 & 12 & 0 \\
$2015-M a y$ 2017* & 107 & $*$ & $*$ & 0 \\
Total 1995-2015 & 161 & 51 & 41 & 0 \\
Total & 268 & 51 & &
\end{tabular}

Note: The duration of the government's term was three years until 2007 and afterwards increased to four. ${ }^{*}$ Until 23 May 2017. Source: own summary based on Misión de Observación Electoral (MOE). 
it as "political party in government" with the same criteria, but this time considering that members of the commission are from the same party as the mayor (like in the city of San Jacinto del Cauca, where the promoters did campaign for the "Partido de la $U$ " in the previous election, and later on joined forces to recall a mayor from the same party). We coded it as "civil society" when none of the members have formal links with parties (that is, no party affiliation was identified and the members did not run for office in previous elections, but we did find enough information on the promoters to proceed with the coding; this is the case of Villarrica where none of the eight members of the commission was identified as a member of any party but they were recognized as civil leaders). We coded it as "mixed" when the commission had a relevant number of both partisan and nonpartisan actors and the partisan actors are not leaders of parties (for example, this is the case of Zambrano, with eight members in the commission, some affiliated to a party and some from civil society). Names of promoters were taken from the Registraduría (requests presented and accepted) and promoters' affiliations were identified through electoral databases giving names and parties running for office (executive and legislative) complemented by Google searches of profiles.

To identify the reasons to activate recall all the formal requests presented at the Registraduría were analysed. This information tends to be general - the most common reason is non-fulfilment of the government plan - thus, we complemented the research with media analysis searching national and local newspapers including also Twitter and Facebook accounts (social networks proved an interesting source of information to assess local campaigns). In order to observe if frequent activations of recall referendums correlate with other social, environmental or violent conflicts, we also compared our cases with datasets on mining and environmental conflicts as well as with the list of territories most affected by the peace agreement with the Revolutionary Armed Forces of Colombia (FARC). ${ }^{29}$ Surprisingly, data do not suggest a correlation between other conflicts and recall activation. For our study, even if the dataset cannot be conclusive, it offers enough information regarding the promoters, the reasons for the activation and the political context of authorities challenged by recall attempts.

To observe the likelihood of suffering a recall referendum by different types of actors, we included data on the affiliation of the mayor (his or her party, movement and or coalitions). We included the electoral results (electoral support) obtained by the executive and the difference to the second party to test whether a clear triumph decreases the likelihood of suffering a recall process. Finally, the effective number of parties was considered based on our own calculations using Laakso and Taagepera's (1979) model and data from the "Registraduría Nacional del Estado Civil". The size of the municipality measuring the number of registered electors was also included. Data were taken from population projections of the "Departamento Administrativo Nacional de Estadística" (DANE). ${ }^{30}$

\section{Analysis}

Our dataset covers all attempts registered between January and May 2017 - a total of 107. Two governors (Quindío and Córdoba) and 85 mayors were challenged by recall processes. On some occasions, an authority was challenged by more than one request (for example, in Barrancabermeja, Bogotá and Planeta Rica, four commissions 
were registered; in Orito, Ocaña and Yopal, three were registered). This reduces the total number of municipalities with recall attempts, but still offers an impressive share of all municipalities (almost $8 \%$, or 85 of circa 1122) given that we are only looking at processes initiated in the first half of 2017. Data to test if these municipalities display higher discontent with the government's performance, greater dissatisfaction with democracy or with public services delivery are unavailable. However, some studies show that Colombian local governments share the Latin American trend of dissatisfaction with local governments (see mainly the "Red Cómo Vamos" programmes in the country's most important cities), ${ }^{31}$ associated with the above-mentioned split between citizens and parties, municipal councils and the resulting crisis of representative democracy.

The first finding of our research refers to the promoters of recall referendums, who are mostly partisan actors. From the 107 commissions registered, we found data for 97 . In 60 cases (61.8\% of all cases), the speaker or most of the members of the commission ran for positions with other parties in a previous election (2015 and/or 2011). In two cases the promoters had supported the mayor in the election of 2015. In 27 cases only civil society actors initiated the request and in eight cases we found mixed commissions of civil and political party members.

Recall requests are mostly oriented towards the government programme. Rather than scandals or other events, the most common accusation refers to dissatisfaction and lack of fulfilment of the government programme. On a few occasions, corruption is also part of the argument (for example, San Benito and Palmito in Sucre, Yopal in Casanere; Lorica in Cordoba). There is no correlation between recall activations and the territories previously in the hands of FARC. In the same vein, only two of our cases were included in the dataset of mining conflicts (Montelíbano and Tasco). We further find no evidence linking the wave of referendums to environmental conflicts. There are cases in which both claims are present (for example, Bogotá and Ibague) but this does not seem to be the explanation for the recall attempt. ${ }^{32}$

These findings suggest that the recall referendum, even if not an exclusive weapon in the hands of parties (note that $27.8 \%$ of the cases were not promoted by party members), is increasingly adapted to be part of the electoral competition. Most of these recall attempts resemble the "impeachment strategy", pointed out by PérezLiñán, used with the intention of interrupting mandates through institutional mechanisms. In other words, a vast majority of attempts are typically led by partisan leaders and only to a lesser extent by actors of civil society.

However, even when the commission was coded as belonging to civil society, our complementary research showed that in several cases there was a former public contractor whose licence was revoked by the new government, which suggests that the recall could be a kind of revenge. There are only eight cases classified as "mixed". However, again, some of these recalls have been launched by former public contractors who lost their contracts with the new administration (for example, the cases of Neiva, San Cayetanos, Barrancavermeja, Planada, Guamo and Trujillo). ${ }^{33}$

Figure 1 shows that attempts are especially - but not only - concentrated in the centre and on the Caribbean coast, regions characterized by the presence of small municipalities, strong patronage structures and an electoral machinery. ${ }^{34}$ There, the citizens' electoral support is given based on a precarious equilibrium between political leaders (for example, a congressmen) and brokers (for example, councillors and neighbourhood leaders) who are able to provide selective incentives to voters (on clientelist bases). Departments (an administrative level between municipalities and national 


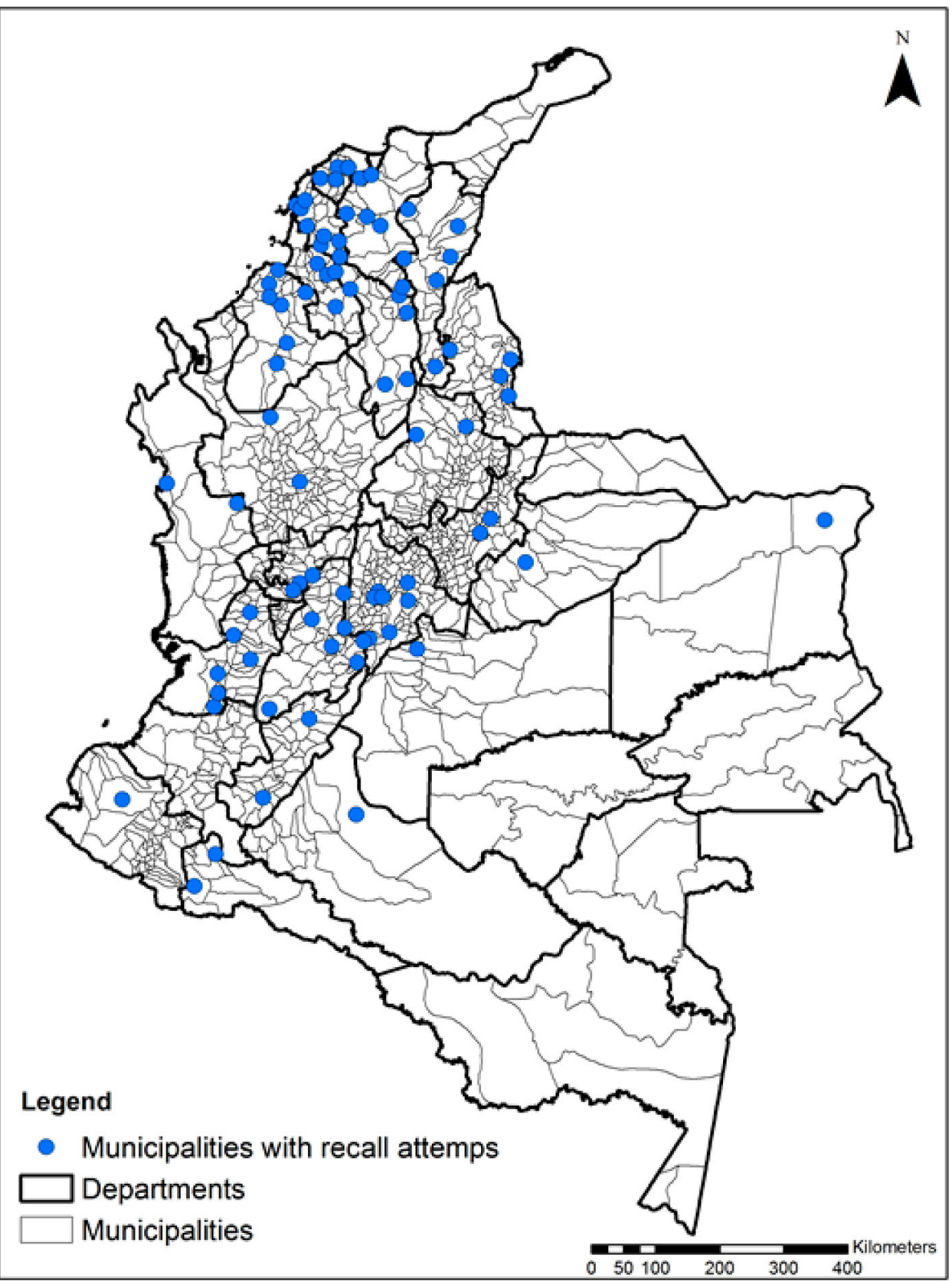

Figure 1. Recall in Colombia.

governments) with more attempts include Bolivar (12), Tolima (7), Cesar, Córdoba, Cundinamarca, Magdalena (each 6) and Valle del Cauca (5); however, there are many others registering one to four attempts in their municipalities.

Regarding the type of parties, there is no clear evidence suggesting that some parties (for example new vs traditional parties) or movements (for example, indigenous people) are more likely to face recall referendums. Even if some parties face more recalls than 
others, this is linked to the number of local governments in the hands of these parties. The correlation is not strictly proportional but suggests a reasonable connection. For instance, parties that performed well in the elections of 2015 (Cambio Radical, Partido de la U, Partido Liberal and to a lesser extent Partido Conservador) face more recalls; for example, the Partido de la $\mathrm{U}$ governs in $16 \%$ of municipalities and faces $15.7 \%$ of total attempts. The situation of the Partido Conservador Colombiano is a bit better, with $13.8 \%$ of municipalities in their hands and $7.8 \%$ of recall processes. $^{35}$ Something similar applies for coalitions and independent candidacies ("Movimientos Significativos de Ciudadanos", launched by a number of signatures). All, traditional or new parties, social movements and independents are equally affected by the challenge of recall.

However, it would be a mistake to assume that recall is oriented to a given political party or a group of political parties stable over time. On the one hand, following Sartori's definition of political parties, ${ }^{36}$ Colombian parties should be characterized by low levels of institutionalization, especially, after the end of the traditional bipartisanism Liberal - Conservador in 2002. ${ }^{37}$

On the other hand, high levels of factionalization are evident since the 1990s, producing "electoral micro-enterprises". ${ }^{38}$ In this sense, the driving force behind recall referendums seems to be systemic and behavioural features. In other words, the high level of party fragmentation and factionalization has fed an extraordinary capacity of pragmatic adaptation, producing organizations characterized by extremely low levels of structuration. 39

At the local level, political organizations allow candidates to manage their own supporters with a high level of autonomy, and conduct different types of alliances and exchanges to arrive to power. However, parties are weak in both their internal organization and cohesion as well as in their links to citizens. The coalitions supporting a candidate are not consistent over time. Our data show that many times the same leaders who supported the candidate during his or her campaign are the sponsors of the recall attempt (for example, the cases of Bucaramanga and Buenavista). This contradicts the common belief assuming that majority governments are protected from these attempts and explains why shortly after an election a new mayor could be challenged by a recall process even if he or she has reached a majority at the previous election.

Regarding the electoral support, as Figure 2 shows, the mayors challenged by a recall attempt gained office with the support of $20 \%$ to $70 \%$ of the electorate, with a median higher than $45 \%$.

The fragmentation of the political party system is also evident in the effective number of parties with seats in the council. However, further research is required to explore the extent to which the existence of a divided government makes a great difference in the activation of recall referendums or, complementary to the explanation, to the extent to which the weakness of the system incentivizes the mentioned "impeachment" strategies. In fact, in most of our cases, the effective number of parties is equal or larger than three, and in $75 \%$ it is higher than six. This reveals the existence of extreme multiparty systems, usually characterized by high transaction costs (between the government and the municipal council) (Figure 3). It potentially increases the incentives to initiate recall proceedings because of the weakness of the mayor.

It is commonly assumed that small municipalities will be more likely to experience recall attempts, given the easiness of collecting signatures as is suggested by the case of Peru. ${ }^{40}$ Thus, the size of the municipality would be correlated with a greater number of 


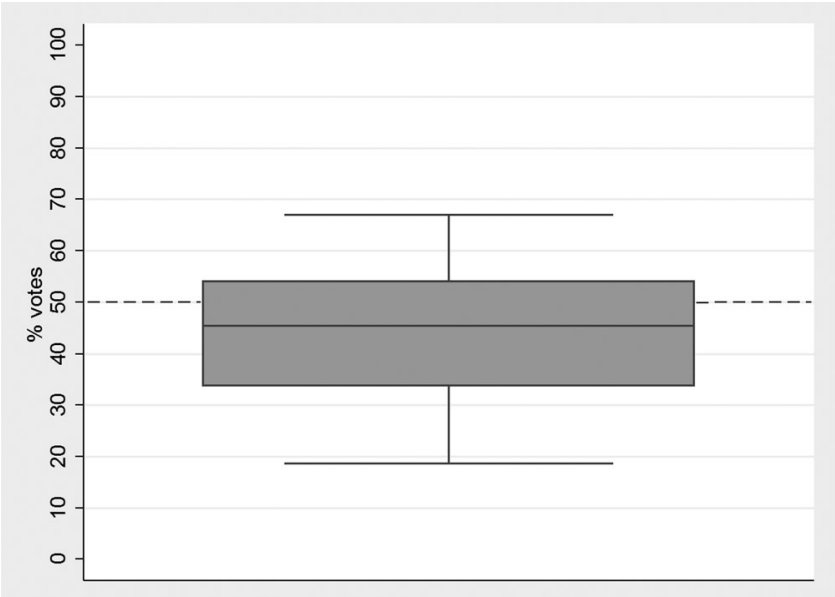

Figure 2. Votes received by challenged mayors.

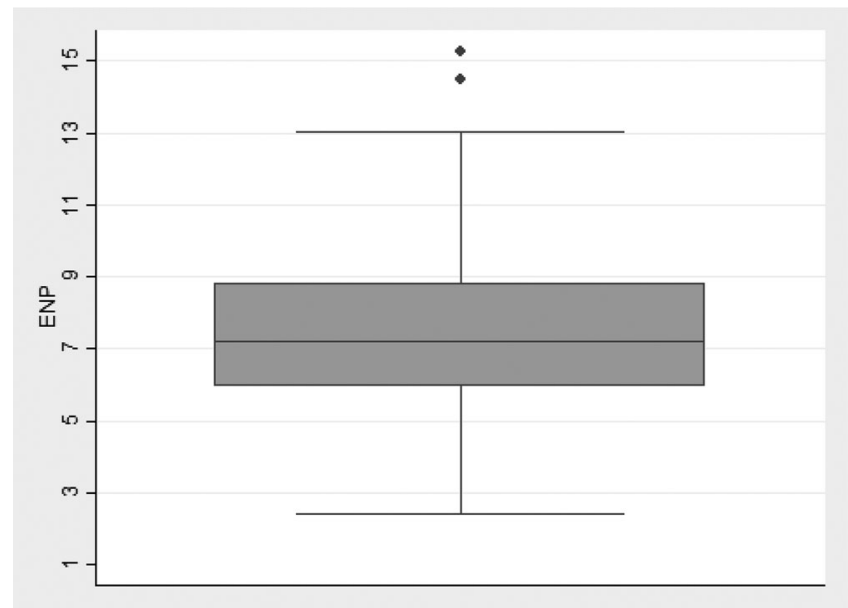

Figure 3. Effective number of parties.

recall activations. Our data show that attempts are concentrated in small and median municipalities. Of these, $75 \%$ are located in municipalities with fewer than 50,000 inhabitants. With a few exceptions (for example, Bogotá, where all mayors in the previous two decades have been challenged by recall announcements, ${ }^{41}$ or Bucaramanga, Cúcuta and Neiva), recall activations are not registered in the biggest municipalities. ${ }^{42}$ However, more research is needed given that this is also related to the higher number of small municipalities.

The activation of recall referendums by political actors in small municipalities could be explained not only by the easiness of collecting signatures but also by the incentives offered in a system in which only the executive is perceived as a relevant prize. Then, the local council is mostly viewed as a trampoline to develop a political career at the 


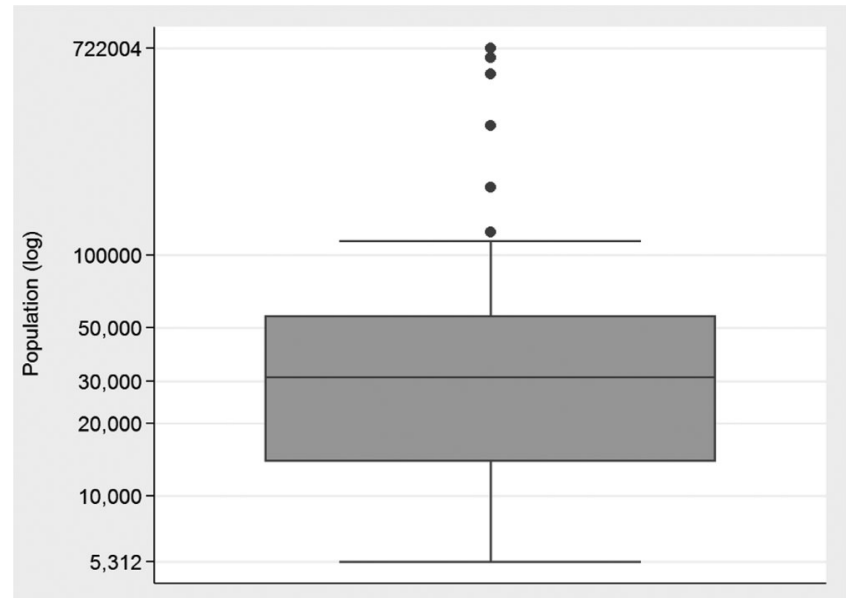

Figure 4. Size of municipalities facing recall attempts.

departmental or national level. In bigger cities, the council tends to be stronger and offers more incentives for politicians (in terms of patronage distribution and access to different kinds of public contracts), while also being able to increase the acceptance of the rules of the game. In this context, in small municipalities, the losers have greater incentives to activate recall referendums against the winner, even if it is unsuccessful, as is happening in Colombia. The attempt of activating a recall referendum could be seen as a form of campaigning and a way to erode the credibility of the mayor (Figure 4).

Finally, it has been suggested that the low turnout facilitates the activation of recall in systems such as Colombia's as well as some US cities ${ }^{43}$ in which the number of signatures is related to the turnout registered at the election of the mayor. In Colombia, some municipal elections are characterized by remarkably low turnouts (that is, with mayors elected with the participation of less than the $35 \%$ of the electorate). However, our data

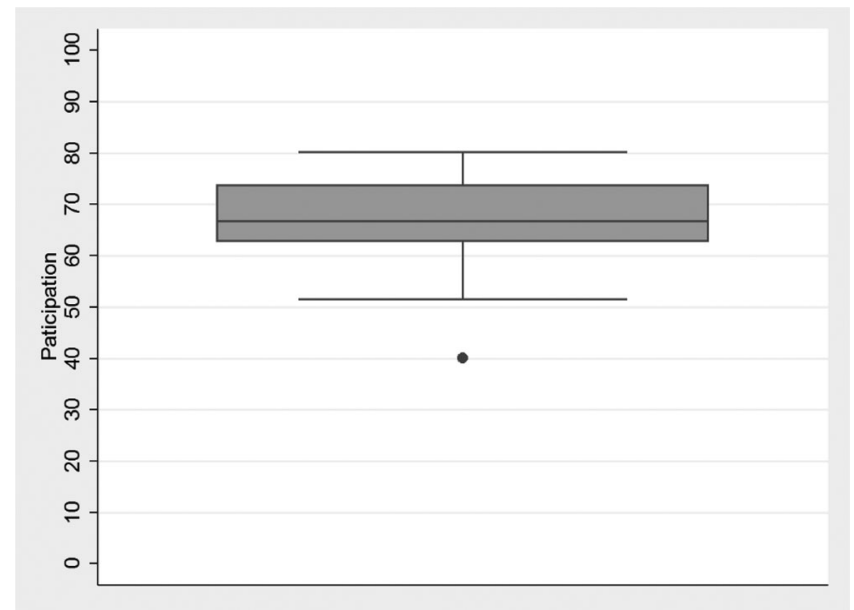

Figure 5. Turnout in municipalities facing recall attempts. 
show that more than $75 \%$ of the municipalities facing recall attempts display high levels of turnout, even slightly higher than the media states (Figure 5).

\section{Conclusions}

In this article we delved into the relationship between recall activations and party competition in Colombia. Our main goal was to systematically analyse to what extent the conditions under which recall is activated are likely to reinforce democratic governance by giving an institutional solution to exceptional problems of legitimacy. However, previous literature suggested that the result could also be the erosion of democracy if recall becomes a weapon to escalate the partisan competition beyond regular elections, producing instability. In order to analyse these questions, we focus on identifying who is behind recall attempts (partisan bodies, civil society or mixed actors) and for what reasons recall is activated (exceptional crisis vs no outstanding reasons). We also analyse to what extent electoral support, situations of divided government, the size of the municipality and the turnout registered in the last election correlate with the number of activations.

Our findings suggest that recall is mostly a weapon in the hands of partisan actors. Sixty percent of the commissions promoting recall were coded as composed by members of opposition parties, while the reasons behind most of these activations were not related to exceptional crisis. We found no correlation between mining and environmental conflicts as well as the territories most affected by the implementation of the peace agreement with our recall dataset.

The findings are strong enough to confirm that recall is not contributing to reinforcing democratic governance in Colombia. Moreover, in a number of commissions launched by civil society actors or by mixed actors we found that the activations were triggered by former state contractors whose connection to government ended after the last election. This supports the idea that in Colombia recall attempts are more frequent in areas dominated by clientelist networks, opening avenues for further research on this connection.

Our data show that a robust electoral support obtained in the previous election is no guarantee for governability, while the formal and informal alliances built prior to an election can easily end once in government. In other words, the volatility of coalitions tends to rapidly produce divided government regardless of the electoral support achieved by the major (in other words, even majority governments could quickly become divided governments). However, this does not only refer to party competition, given that party labels do not always play a major role. The decisive driver of recall is the (changing) political support of individuals in a scenario of high fragmentation and personalization of politics. Support occurs due to a delicate balance based on the sum of various political leaders and their capacity to sustain the clientelist network. Accordingly, the logic behind most of the attempts of removing an executive from office can be compared to the electoral weakness leading to a presidential impeachment. However direct recall gives a role to citizens in the process of signature collection and in the vote and also becomes a tool for other actors (for example, contractors).

Recall attempts are more frequent in small municipalities. This could be related to the incentives (political prizes) that this kind of district produces, as well as to strategies related to the political projection of the opponents. However, this trend has 
also been observed in other places, from Peru to Poland capitals or big cities are also challenged by recall, indicating that further research is required to arrive at conclusive results.

Our findings invite policy makers to rethink whether the need to increase legitimacy and conflict resolution, especially in the context of the peace agreement implementation, should be answered by facilitating the activation of institutions like recall.

\section{Notes}

1. Hug and Tsebelis, "Veto Players and Referendums around the World."

2. See Welp, "Recall Referendums in Peruvian Municipalities"; and Tuesta Soldevilla, Una onda expansiva.

3. Serdült and Welp, "The Levelling up of a Political Institution"; see note 2.

4. See the introduction to this special issue by Whitehead.

5. Guzmán, "Cuba."

6. See Bowler, "Recall and Representation."

7. As described by Serdült to refer to a non-used institution. See Serdült, "A Dormant Institution."

8. Taiwan is the fifth. See note 4 and also Welp, "Recall Referendum around the World."

9. Guzmán, "Cuba."

10. Data from CNE.

11. Data from Jurado Nacional de Elecciones.

12. Franco-Cuervo, "La revocatoria del mandato en Colombia"; Tuesta Soldevilla, Una onda expansiva.

13. Serdült, "A Dormant Institution."

14. Dalton, Bürklin, and Drummond, "Public Opinion and Direct Democracy."

15. See Okamoto and Serdült in this special issue.

16. Kriesi, "The Role of the Political Elite in Swiss Direct-Democratic Votes."

17. See Serdült and Welp, "Direct Democracy Upside Down."

18. Pérez-Liñán, "Presidential Impeachment and the New Political Instability in Latin America."

19. Hochstetler, Rethinking Presidentialism; Pérez-Liñán, "A Two-Level Theory of Presidential Instability"; Marsteintredet, Llanos, and Nolte, "Paraguay and the Politics of Impeachment."

20. Levitsky and Cameron, "Democracy Without Parties?"; Freidenberg and Suárez-Cao, Territorio $y$ Poder.

21. See note 8 .

22. Pachón and Shugart, "Electoral Reform and the Mirror Image of Inter-Party and Intra-Party Competition"; Pachón and Johnson, "When's the Party (or Coalition)?"

23. See Carty, "Parties as Franchise Systems."

24. Milanese and Barrero, "Selección de candidatos en escenarios de atomización dirigencial, análisis de los casos de Cali y el Valle del Cauca."

25. Levitsky and Cameron, "Democracy Without Parties?"

26. Sartori, Parties and Parties Systems.

27. For a similar analysis of the Peruvian case see Welp, "Recall Referendums in Peruvian Municipalities."

28. The process is summarized here (only in Spanish) http://www.registraduria.gov.co/IMG/pdf/ REVOCATORIA_DEL_MANDATO_BULLETS_-_CLN.pdf.

29. Data were taken from the Observatorio de Conflictos Mineros en América Latina (https://www. ocmal.org) and from Hincapié's dataset (see Hincapié, "Extractivismo, consultas populares y derechos politicos").

30. Data are available at https://www.dane.gov.co/index.php/estadisticas-por-tema/demografia-ypoblacion/proyecciones-de-poblacion.

31. http://redcomovamos.org/

32. We thank Sandra Hincapié for her support contrasting both datasets on recall and environmental conflicts.

33. Many recall promotors were found in the the database "Colombia Compra Eficiente" (database of the Colombian procurement system). 
34. See Langbein and Sanabria, "The Shape of Corruption"; Escobar, "Clientelism and Citizenship"; Archer, "The Transition from Traditional to Broker Clientelism in Colombia."

35. Data for municipalities by party were taken from Pico, Rocío, and García García, "Elecciones del 2015 en Colombia."

36. See note 27.

37. See Milanese and Barrero, "Selección de candidatos en escenarios de atomización dirigencial, análisis de los casos de Cali y el Valle del Cauca"; Gutiérrez Sanín, ¿Lo que el viento se llevó?

38. Pizarro, "Gigantes con pies de barro."

39. The electoral reform of 2003, oriented to increase the incentives for party aggregation, failed in its goals. See Shugart, Moreno, and Fajardo, "Deepening Democracy through Renovating Political Practices"; Milanese and Barrero, "Selección de candidatos en escenarios de atomización dirigencial, análisis de los casos de Cali y el Valle del Cauca."

40. See Welp, "Recall Referendums in Peruvian Municipalities"; and Tuesta Soldevilla, Una onda expansiva.

41. See Uribe, "La activación de la revocatoria de mandato en el ámbito municipal en Colombia"; and Franco-Cuervo, "La activación de la revocatoria del mandato en Colombia."

42. Law 617 of 2000 establishes seven categories of municipalities, from one (those with population greater than 500,001 inhabitants), to the seventh category (with fewer than 10,000). This category determines the volume of resources of free investment that each municipality will receive.

43. See Spivak's arguments for the US. Spivak, "California's Recall."

44. For Argentina see Arques, "Argentina"; for Bolivia Verdugo Silva, "Bolivia"; for Colombia Franco-Cuervo, "La revocatoria del mandato en Colombia"; and MOE, "Mecanismos de Participación Ciudadana en Colombia”; for Cuba Guzmán Hernández, "Cuba”; for Ecuador Ramírez, "El despliegue de la democracia directa en el Ecuador posconstitucional"; and Castellanos Santamaría, "Ecuador"; for Mexico Limón, "Revocación del mandato en México"; for Peru Tuesta Soldevilla, Una onda expansiva; and Welp, "Recall Referendums in Peruvian Municipalities"; for Venezuela Kornblith, "Revocatoria del mandato presidencial en Venezuela."

45. Arques, "Argentina."

46. Limón, "Revocación del mandato en México."

\section{Acknowledgements}

We would like to thank Laurence Whitehead and the three anonymous reviewers for their useful comments on previous versions of this article. We also want to thank Fabian Acuña and Sandra Hincapié for their help in clarifying specific issues.

\section{Disclosure statement}

No potential conflict of interest was reported by the authors.

\section{Notes on contributors}

Yanina Welp is currently principal researcher at the Center for Democracy Studies and co-director of the Zurich - Latin American Center, both at the University of Zurich.

Juan PabloMilanese is Associate Professor of the Political Studies Department at Universidad Icesi.

\section{Bibliography}

Archer, Ronald. "The Transition from Traditional to Broker Clientelism in Colombia: Political Stability a Social Unrest.” Kellogg Institute Working Paper \#140 - July1990.

Arques, Facundo. "Argentina: una herramienta de los gobernados en manos de los gobernantes." In $\mathrm{La}$ dosis hace el veneno: la revocatoria del mandato en Suiza, Estados Unidos y América Latina, edited by Yanina Welp and Uwe Serdült, 159-186. Quito: Serie Ciencia y Democracia, Consejo Nacional Electoral, 2014. 
Bowler, Shaun. "Recall and Representation: Arnold Schwarzenegger Meets Edmund Burke." Representation 40, no. 3 (2004): 200-212. doi:10.1080/00344890408523266.

Carty, Kenneth. "Parties as Franchise Systems. The Stratarchial Organizational Imperative." Party Politics 10, no. 1 (2004): 5-24. doi:10.1177/1354068804039118.

Castellanos Santamaría, Ana Sofía. "Ecuador: la transformación de las reglas del juego y sus consecuencias (1998-2013)." In La dosis hace el veneno: la revocatoria del mandato en Suiza, Estados Unidos y América Latina, edited by Yanina Welp, and Uwe Serdült, 83-110. Quito: Serie Ciencia y Democracia, Consejo Nacional Electoral, 2014.

Dalton, Russell J., Wilhelm P. Bürklin, and Andrew Drummond. 2001. "Public Opinion and Direct Democracy." Journal of Democracy 12 (4): 141-153. doi:10.1007/978-3-322-95630-9_16.

Escobar, Cristina. "Clientelism and Citizenship. The Limits of Democracy Reform in Sucre, Colombia." Latin American Perspectives 29, no. 5 (2002): 20-47. doi:10.1177/0094582X0202900503.

Franco-Cuervo, Ana Beatriz. "La revocatoria del mandato en Colombia." In La dosis hace el veneno. La revocatoria del mandato en Suiza, Estados Unidos y América Latina, edited by Yanina Welp, and Uwe Serdül, 89-124. Quito: Serie Ciencia y Democracia, Consejo Nacional Electoral, 2014.

Freidenberg, Flavia, and J. Suárez-Cao, eds. Territorio y Poder: Nuevos actores y competencia política en los sistemas de partidos multinivel en América Latina. Salamanca: Ediciones Universidad de Salamanca, 2014.

Gutiérrez Sanín, Francisco. ¿Lo que el viento se llevó? Los partidos políticos y la democracia en Colombia, 1958-2002? Bogotá: Norma, 2007.

Guzmán Hernández, Yan. "Cuba: deudas pasadas y retos presentes desde la norma.” In La dosis hace el veneno: la revocatoria del mandato en Suiza, Estados Unidos y América Latina, edited by Yanina Welp and Uwe Serdült, 187-205. Quito: Serie Ciencia y Democracia, Consejo Nacional Electoral, 2014.

Hincapié, Sandra. "Extractivismo, consultas populares y derechos políticos ¿El renacimiento de la democracia local en Colombia?" Reflexión Política 19, no. 37, (2017): 86-99. http://revistas.unab. edu.co/index.php?journal=reflexion\&page $=$ article\&op=viewArticle\&path\%5B\%5D=2769.

Hochstetler, Kathryn. "Rethinking Presidentialism: Challenges and Presidential Falls in South America." Comparative Politics 38, no. 4 (2006): 401-418. doi:10.1177/0192512115604904.

Hug, Simon and George Tsebelis. "Veto Players and Referendums around the World." Journal of Theoretical Politics 14, no. 4 (2002): 465-515. doi:10.1177/095169280201400404.

Kornblith, Miriam. "Revocatoria del mandato presidencial en Venezuela: definición y puesta en práctica." In Democracias en movimiento. Mecanismos de democracia Directa y participativa en América, edited by Alicia Lissidini, Yanina Welp and Daniel Zovatto, 131-166. México, DF: Universidad Nacional Autónoma de México, 2014.

Kriesi, Hansperter. "The Role of The Political Elite in Swiss Direct-Democratic Votes." Party Politics 12, no. 5 (2006): 599-622. doi:10.1007/978-3-531-90579-2_7.

Langbein, Laura and Pablo Sanabria. "The Shape of Corruption: Colombia as a Case Study." The Journal of Development Studies 49, no. 11 (2013): 2-14. doi:10.1080/00220388.2013.800858.

Levitsky, Steven and Cameron Maxwell. "Democracy Without Parties? Political Parties and Regime Change in Fujimori's Peru." Latin American Politics and Society 45, no. 3 (2003): 1-33. doi:10. 1111/j.1548-2456.2003.tb00248.x.

Limón, Walter. "Revocación del mandato en México." c2d Working Papers Series 51, Zentrum für Demokratie Aarau (ZDA), 2016.

Marsteintredet, Leiv and Mariana Llanos and Detlef Nolte. "Paraguay and the Politics of Impeachment." Journal of Democracy 24, no. 4 (2013): 110-123. https://www. journalofdemocracy.org/article/paraguay-and-politics-impeachment.

Milanese, Juan Pablo and Fredy Andrés Barrero. "Selección de candidatos en escenarios de atomización dirigencial. Análisis de los casos de Cali y el Valle del Cauca, elecciones locales y regionales 2015." Análisis Político 29, no. 88 (2016): 68-89. doi:10.15446/anpol.v29n88.63602.

MOE (Misión de Observación Electoral). Mecanismos de Participación Ciudadana en Colombia -20 años de ilusiones-. Bogotá, September 2012.

Pachón, Mónica and Gregg Johnson. "When's the Party (or Coalition)? Agenda-Setting in a Highly Fragmented, Decentralized Legislature." Journal of Politics in Latin America 8, no. 2 (2016): 71100. https://journals.sub.uni-hamburg.de/giga/jpla/article/view/959/966. 
Pachón, Mónica and Matthew S. Shugart. "Electoral Reform and the Mirror Image of Inter-Party and Intra-Party Competition: The Adoption of Party Lists in Colombia." Electoral Studies 29, no. 4, (2010): 648-660. doi:10.1016/j.electstud.2010.06.005.

Peréz-Liñán, Aníbal. "Presidential Impeachment and the New Political Instability in Latin America." Cambridge: Cambridge University Press, 2007.

Pérez-Liñán, Anibal. "A Two-Level Theory of Presidential Instability." Latin American Politics and Society 56, no. 1 (2014): 34-54. doi:10.1111/j.1548-2456.2014.00220.x.

Pico, Rodíguez, Clara Rocío and Diva Marcela García García. "Elecciones del 2015 en Colombia: partidos políticos y selección de candidatos en el ámbito subnacional." Análisis Político 29, no. 88 (2016): 3-27. doi:10.15446/anpol.v29n88.63515.

Pizarro, Eduardo. "Gigantes con pies de barro: los partidos políticos en Colombia." In La crisis de representación democrática en los países andinos, edited by Scott Mainwaring and Ana María Bejarano, 133-162. Bogotá: Norma, 2008.

Ramírez Gallegos, Franklin. "El despliegue de la democracia directa en el Ecuador posconstitucional." In Democracias en movimiento, (comp.) Lissidini, A., Welp, Y. and Zovatto, D., 231-273. México, UNAM, 2014.

Sartori, Giovanni. Parties and Party Systems. A Framework for Analysis. New York: Cambridge University Press, 1976.

Serdült, Uwe. "A Dormant Institution - History, Legal Norms and Practice of the Recall in Switzerland." Representation - Journal of Representative Democracy 51, no. 2 (2015): 161-172. doi:10.1080/00344893.2015.1056219.

Serdült, Uwe and Yanina Welp. "Direct Democracy Upside Down." Taiwan Journal of Democracy 8, no. 1 (2012): 69-92. http://www.tfd.org.tw/export/sites/tfd/files/publication/journal/dj0801/004. pdf.

Serdült, Uwe, and Yanina Welp. "The Levelling up of a Political Institution. Perspectives on the Recall Referendum." In Let the People Rule? Direct Democracy in the Twenty-First Century, edited by Saskia P. Ruth, Yanina Welp, and Laurence Whitehead, 137-154. Colchester: ECPR Press, 2017.

Shugart, Matthew S., Erika Moreno and Luis Fajardo. "Deepening Democracy by Renovating Political Practices: The Struggle for Electoral Reform in Colombia." In Peace, Democracy, and Human Rights in Colombia, edited by Christopher Welna and Gustavo Gallón, 202-266. South Bend: Notre Dame University Press, 2007.

Spivak, Joshua. "California's Recall: Adoption of the 'Grand Bounce' for Elected Officials." California History 82, no. 2 (2004): 20-63. doi:10.2307/25161725.

Tuesta Soldevilla, Fernando, ed. Una onda expansiva. Lima: Jurado Nacional de Elecciones, 2014.

Uribe Mendoza, Cristhian. "La activación de la revocatoria de mandato en el ámbito municipal en Colombia. Lecciones del caso de Bogotá." Estudios Políticos, 48 (2016): 179-200. doi:10.17533/ udea.espo.n48a10.

Verdugo Silva, Julio Teodoro. "Bolivia: entre la expectativa de uso y los intentos fallidos de activación." In La dosis hace el veneno: la revocatoria del mandato en Suiza, Estados Unidos y América Latina, edited by Yanina Welp, and Uwe Serdült, 135-158. Quito: Serie Ciencia y Democracia, Consejo Nacional Electoral, 2014.

Welp, Yanina. "Recall Referendums in Peruvian Municipalities: A Political Weapon for Bad Losers or an Instrument of Accountability?" Democratization 23, no. 7 (2016): 1162-1179. doi:10.1080/ 13510347.2015.1060222.

Welp, Yanina. "Recall Referendum Around the World: Origins, Institutional Designs and Current Debates." In The Routledge Handbook to Referendums and Direct Democracy, edited by Laurence Morel, Matt Qvortrup, 451-463. Routledge, Forthcoming 2018.

Welp, Yanina and Serdült, Uwe, eds. La dosis hace el veneno: La revocatoria del mandato en Suiza, Estados Unidos y América Latina. Quito: Consejo Nacional Electoral, 2014. 